\title{
Pierson Syndrome
}

National Cancer Institute

\section{Source}

National Cancer Institute. Pierson Syndrome. NCI Thesaurus. Code C128145.

An autosomal recessive disorder caused by mutation(s) in the LAMB2 gene, encoding laminin subunit beta-2. It is characterized by congenital nephrotic syndrome with diffuse mesangial sclerosis and distinct ocular abnormalities. 